\title{
Hidden reservoirs in the continental lithosphere? Evidence from Hf-Sr-Nd-Pb isotopes in southern African kimberlite megacrysts
}

\author{
Philip E. Janney ${ }^{1 *}$ \& David R. Bell ${ }^{2}$ \\ ${ }^{1}$ Department of Geological Sciences, University of Cape Town, Rondebosch 7701, South Africa \\ ${ }^{2}$ AEON-ESSRI, Nelson Mandela Metropolitan University, Summerstrand 6031, South Africa
}

\section{Introduction}

Hidden mantle reservoirs with anomalous isotopic compositions have been proposed to explain apparent differences between the isotopic composition of the upper mantle as inferred from oceanic basalts and estimates of bulk silicate earth (BSE) composition based on chondrite meteorites (e.g., ${ }^{142} \mathrm{Nd} /{ }^{144} \mathrm{Nd}$ ). In particular, the displacement of the $\mathrm{Nd}-\mathrm{Hf}$ isotopic oceanic basalt array away from the BSE composition toward slightly more radiogenic ${ }^{176} \mathrm{Hf} /{ }^{177} \mathrm{Hf}$ values has prompted speculation that a hidden mantle reservoir exists that has relatively unradiogenic $\varepsilon_{\mathrm{Hf}}$ for a given $\varepsilon_{\mathrm{Nd}}$ value (Bizzarro et al., 2002). The presence of anomalously unradiogenic $\varepsilon_{\mathrm{Hf}}$ relative to $\varepsilon_{\mathrm{Nd}}$ in kimberlites and their megacrysts has been explained as the signature of ancient subducted oceanic crust (MORB and/or OIB) segregated at a deep mantle boundary layer, such as the transition zone or core-mantle boundary, constituting a hidden reservoir in the deep mantle (Nowell et al., 2004). Moreover, the presence of such isotopic signatures, which lie outside the range of modern oceanic basalts, has been used to argue for a deep mantle plume origin for kimberlites (Tappe et al., 2013). More recent refinement of chondrite Nd-Hf isotopic compositions (Bouvier et al., 2008) has removed the necessity for a hidden reservoir to reconcile the composition of oceanic basalts with a chondritic mantle, but the unusual Hf-Nd isotopic compositions of kimberlites and megacrysts still requires explanation.

$\mathrm{We}$ present $\mathrm{Hf}-\mathrm{Sr}-\mathrm{Nd}-\mathrm{Pb}$ isotopic and trace element evidence from clinopyroxene megacrysts from seven Cretaceous southern African kimberlites that (1) requires the presence of a component having anomalously unradiogenic $\mathrm{Hf}$ and "enriched mantle" characteristics (unradiogenic $\varepsilon_{\mathrm{Nd}}$ and ${ }^{206} \mathrm{~Pb} /{ }^{204} \mathrm{~Pb}$, radiogenic ${ }^{87} \mathrm{Sr} /{ }^{86} \mathrm{Sr}$ ) within the continental lithospheric mantle and (2) suggests the ubiquitous presence of a strong HIMU mantle source with a chemical signature of carbonatite metasomatism in the deep lithosphere or asthenosphere beneath southern Africa.
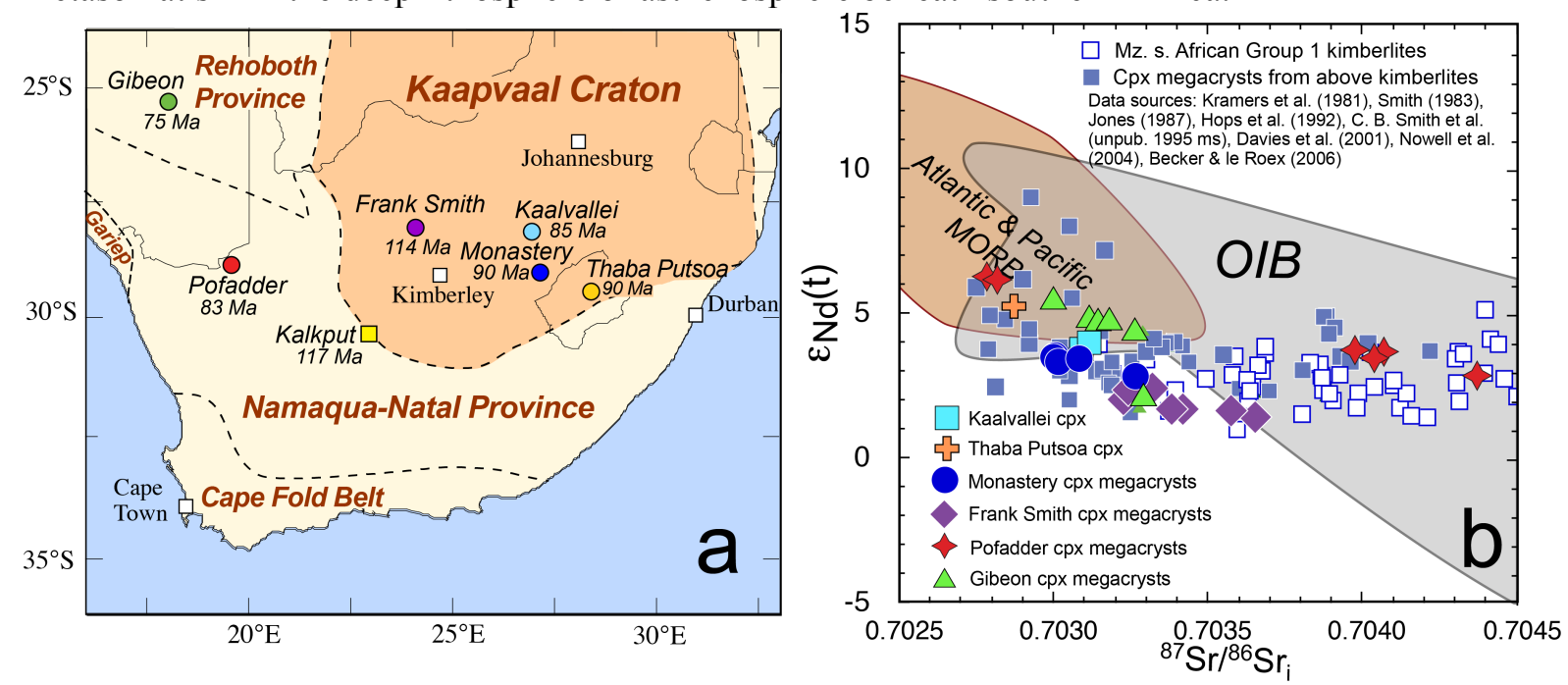

Figure 1. (a) Map of kimberlites from which clinopyroxene megacrysts in this study were analysed. (b) ${ }^{87} \mathrm{Sr} /{ }^{87} \mathrm{Sr}$ vs. $\varepsilon_{\mathrm{Nd}}(\mathrm{t})$ plot for the studied Group 1 kimberlite megacrysts along with literature data.

\section{Approach and Results}

Approximately 30 clinopyroxene megacrysts from seven Cretaceous southern African kimberlites/clusters (Fig. 1; six Group 1 and one Group 2) were analysed for trace elements and Hf$\mathrm{Sr}-\mathrm{Nd}-\mathrm{Pb}$ isotope compositions using ultra-low blank methods, mainly at Arizona State University. For four of these (Monastery, Frank Smith, Gibeon and Pofadder, all Group I), six or more 
megacrysts were analysed from each so as to cover a range of compositions (Cr-poor to $\mathrm{Cr}$-rich) and crystallization temperatures (based on $\mathrm{Ca} \#=100 * \mathrm{Ca} /(\mathrm{Ca}+\mathrm{Mg})$ in atomic \%). For each of these megacryst suites, the sample with the highest crystallization temperature (lowest $\mathrm{Ca}$ ) has the lowest ${ }^{87} \mathrm{Sr}^{86} \mathrm{Sr}_{\mathrm{i}}(0.7027-0.7032)$, highest $\varepsilon_{\mathrm{Nd}}(\mathrm{t})(+3.5$ to +6.5$)$ and highest ${ }^{206} \mathrm{~Pb} /{ }^{204} \mathrm{~Pb}_{\mathrm{i}}$ ratios $(19.6-20.7)$, similar to the 'HIMU' or 'FOZO' source components of ocean island basalts, and has $\varepsilon_{\mathrm{Nd}}-\varepsilon_{\mathrm{Hf}}$ values that fall only slightly below the global Nd-Hf oceanic basalt array. As crystallization temperatures decrease, the ${ }^{87} \mathrm{Sr} /{ }^{86} \mathrm{Sr}$ values of the megacrysts increase and $\varepsilon_{\mathrm{Nd}}$, $\varepsilon_{\mathrm{Hf}}$ and ${ }^{206} \mathrm{~Pb} /{ }^{204} \mathrm{~Pb}$ values all decrease. The samples crystallizing at the lowest temperatures typically fall furthest (up to $8.5 \mathrm{eHf}$ units) below the Nd-Hf oceanic basalt array. This pattern is most easily explained by assimilation of a lithospheric component that has anomalously low $\varepsilon_{\mathrm{Hf}}$ compared to $\varepsilon_{\mathrm{Nd}}$, combined with high ${ }^{87} \mathrm{Sr} /{ }^{86} \mathrm{Sr}$ and low $\varepsilon_{\mathrm{Nd}}$ and ${ }^{206} \mathrm{~Pb} /{ }^{204} \mathrm{~Pb}$ values. The above isotopic variations are also accompanied by increases in $\mathrm{Zr}$ and $\mathrm{Hf}$ concentrations and decreases in $(\mathrm{Lu} / \mathrm{Hf})_{\mathrm{N}}$ ratios.
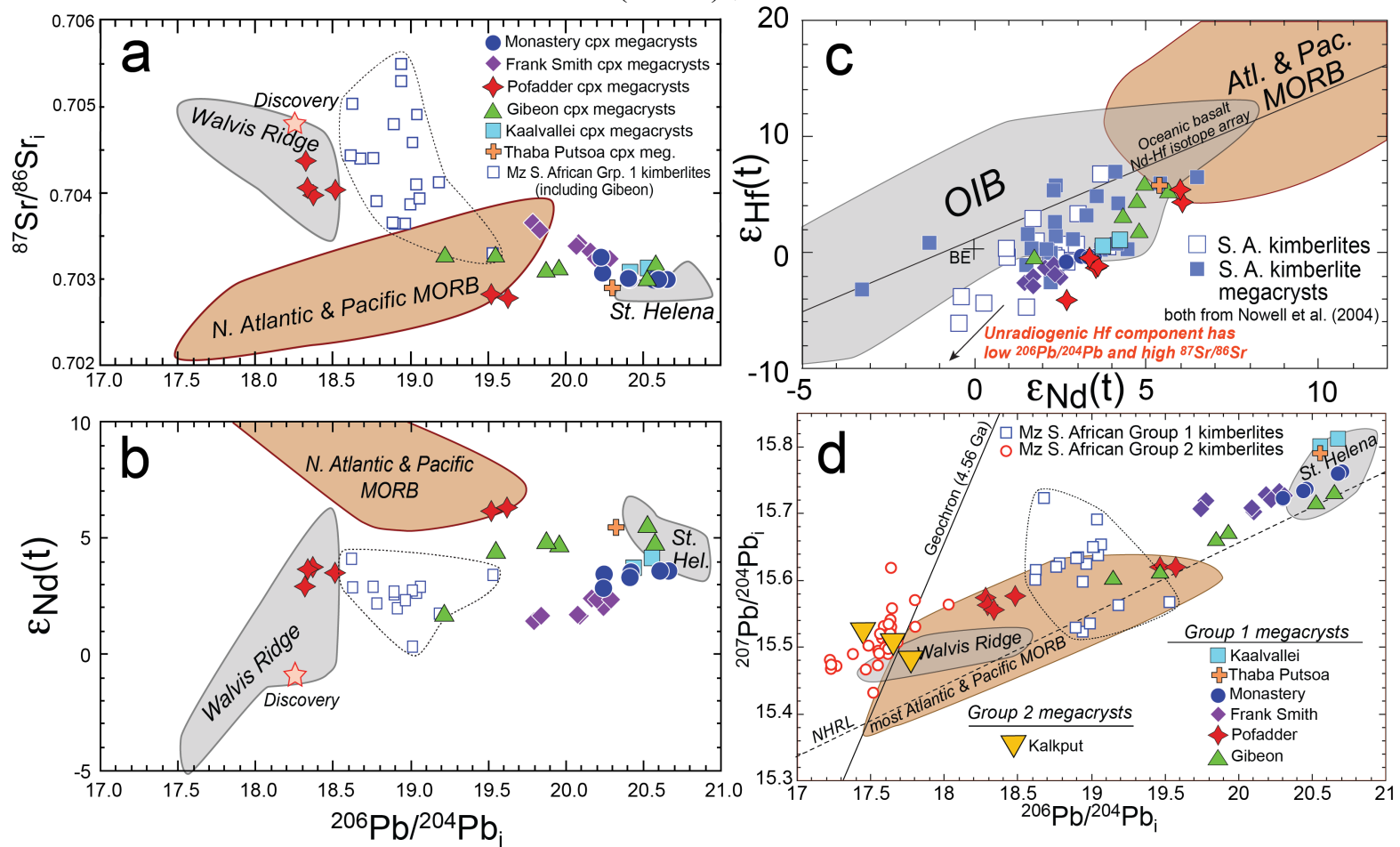

Figure 2. Isotope ratios plots for clinopyroxene megacrysts: (a) ${ }^{206} \mathrm{~Pb} /{ }^{204} \mathrm{~Pb}$ vs ${ }^{87} \mathrm{Sr} /{ }^{86} \mathrm{Sr}$, (b) ${ }^{206} \mathrm{~Pb} /{ }^{204} \mathrm{~Pb}$ vs. $\varepsilon_{\mathrm{Nd}}(\mathrm{t})$, (c) $\varepsilon_{\mathrm{Nd}}(\mathrm{t})$ vs $\varepsilon_{\mathrm{Hf}}(\mathrm{t})$ and $(\mathrm{d}){ }^{206} \mathrm{~Pb} /{ }^{204} \mathrm{~Pb}$ vs. ${ }^{207} \mathrm{~Pb} /{ }^{204} \mathrm{~Pb}$. Kimberlite data are from Figure 1 plus Fraser and Hawkesworth (1992).

\section{Discussion}

We propose that southern African Group 1 and Group 2 kimberlites preferentially assimilate metasomatic vein components in the lithospheric mantle analogous to the phlogopite-ilmeniteclinopyroxene (PIC) and MARID xenolith suites, respectively. Chemical data suggest that PIC and MARID xenoliths have low and moderate $\mathrm{Lu} / \mathrm{Hf}$ ratios, respectively, relative to $\mathrm{Sm} / \mathrm{Nd}$ (Gregoire et al., 2002), and over time could evolve appropriately unradiogenic $\mathrm{Hf}$ and $\mathrm{Nd}$ isotopic compositions lying below and on the Hf-Nd isotopic array, respectively.

The prevalence of the strong HIMU isotopic signature in Cr-poor clinopyroxenes from all Cretaceous Group 1 kimberlite megacryst suites investigated, whether on on-craton or off-craton, is intriguing and suggests that this mantle source composition is not derived from localised, deep-seated mantle plumes. The Group 1 megacryst suite that shows the weakest HIMU signature (Pofadder) is strongly dominated by $\mathrm{Cr}$-rich megacryst compositions, suggesting that its HIMU signature may have been diluted at shallow levels. Further, the fact that the Cr-poor megacrysts tend to show strong negative anomalies in $\mathrm{Zr}$ and $\mathrm{Hf}$ (and often $\mathrm{Ti}$ ) appears to support the possibility that this HIMU signature could have developed in the deep lithosphere in-situ by a metasomatic process involving recycled carbonatitic material, in a scenario similar to that envisioned by Weiss et al. (2016). 

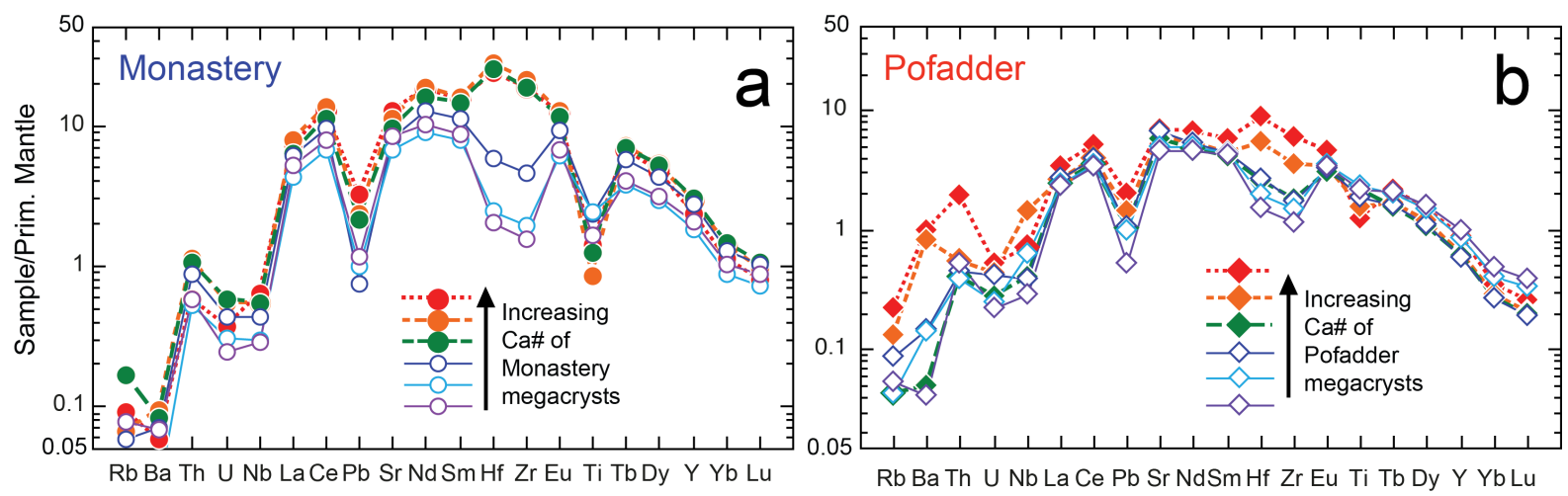

Figure 3. Primitive mantle-normalised incompatible element diagrams for (a) Monastery and (b) Pofadder clinopyroxene megacrysts. Note the depletion in $\mathrm{Zr} \& \mathrm{Hf}$ and the change in these elements with decreasing crystallization temperature (i.e., increasing Ca\#). Normalising values from McDonough \& Sun (1995)

\section{Acknowledgements}

Generous support for this project was provided by the U.S. National Science Foundation (to PEJ and DRB) and the South African National Research Foundation and the UCT Science Faculty to PEJ.

\section{References}

Becker, M. \& le Roex, A. P. (2006). Geochemistry of South African on- and off-craton, Group I and Group II kimberlites: Petrogenesis and source region evolution. Journal of Petrology 47, 673-703.

Bizzarro, M., Simonetti, A., Stevenson, R. K. \& David, J. (2002). Hf isotope evidence for a hidden mantle reservoir. Geology 30, 771-774.

Bouvier, A., Vervoort, J. D. \& Patchett, J. D. (2008). The Lu-Hf and Sm-Nd isotopic composition of CHUR: constraints from unequilibrated chondrites and implications for the bulk composition of terrestrial planets. Earth and Planetary Science Letters 273, 48-57.

Davies, G. R., Spriggs, A. J. \& Nixon, P. H. (2001). A non-cognate origin for the Gibeon kimberlite megacryst suite, Namibia: Implications for the origin of Namibian Kimberlites. Journal of Petrology 42, 159-172.

Davis, G., Krogh, T. \& Erlank, A. J. (1976). The ages of zircons from kimberlites from South Africa. Carnegie Institution Yearbook 75, 821-824.

Fraser, K.J. \& Hawkesworth, C.J. (1992). The petrogensis of group 2 ultrapotassic kimberlites from Finsch Mine, South Africa. Lithos 28, 327-345.

Gregoire, M., Bell, D. R. \& le Roex, A. P. (2002). Trace element geochemistry of phlogopite-rich mafic mantle xenoliths: their classification and their relationship to phlogopite-bearing peridotites and kimberlites revisited. Contributions to Mineralogy and Petrology 142, 602-625.

Griffin, W. L., Batumike, J. M., Greau, Y., Pearson, N. J., Shee, S. R. \& O'Reilly, S. Y. (2014). Emplacement ages and sources of kimberlites in southern Africa: $\mathrm{U}-\mathrm{Pb}$ ages and $\mathrm{Sr}-\mathrm{Nd}$ isotopes of groundmass perovskite. Contributions to Mineralogy and Petrology 168, paper 1032.

Hops, J. J., Gurney, J. J. \& Harte, B. (1992). The Jagersfontein Cr-poor megacryst suite - towards a model for megacryst petrogenesis. Journal of Volcanology and Geothermal Research 50, 143-160.

Jones, R. A. (1987). Strontium and neodymium isotopic and rare earth element evidence for the genesis of megacrysts in kimberlites of southern Africa. In: Nixon, P. H. (ed.) Mantle Xenoliths. London: John Wiley \& Sons, 711-724.

Kramers, J. D., Smith, C. B., Lock, N. P., Harmon, R. S. \& Boyd, F. R. (1981). Can kimberlites be generated from an ordinary mantle? Nature 291, 53-56.

McDonough, W. F. \& Sun, S. S. (1995). The composition of the Earth. Chemical Geology 120, 223-253.

Nowell, G. M., Pearson, D. G., Bell, D. R., Carlson, R. W., Smith, C. B., Kempton, P. D. \& Noble, S. R. (2004). Hf isotope systematics of kimberlites and their megacrysts: New constraints on their source regions. Journal of Petrology 45, 1583-1612.

Smith, C. B. (1983). Pb, $\mathrm{Sr}$ and $\mathrm{Nd}$ isotopic evidence for sources of southern African Cretaceous kimberlites. Nature 304, 51-54.

Tappe, S., Pearson, D. G., Kjarsgaard, B. A., Nowell, G., \& Dowall, D. (2013). Mantle transition zone input to kimberlite magmatism near a subduction zone: origin of anomalous $\mathrm{Nd}-\mathrm{Hf}$ isotope systematics at Lac de Gras, Canada. Earth and Planetary Science Letters, 371, 235-251.

Weiss, Y., Class, C., Goldstein, S. L. \& Hanyu, T. (2016). Key new pieces of the HIMU puzzle from olivines and diamond inclusions. Nature 537, 666-670. 